\title{
Standardization of Recipes for Preparation of Pumpkin (Cucurbita moschata) Flour and its Quality Evaluation during Storage
}

\author{
Sachin Mittal ${ }^{1 *}$, Anju K Dhiman ${ }^{1}$, Anshu Sharma ${ }^{1,2}$, Surekha Attri ${ }^{1}$ \\ and Deepika Kathuria ${ }^{1}$
}

${ }^{1}$ Department of Food Science and Technology, Dr YS Parmar University of Horticulture and Forestry, Nauni, Solan - 173230, Himachal Pradesh, India

${ }^{2}$ Amity International Centre for Post Harvest and Technology, Amity University, Noida201303, Uttar Pradesh, India

*Corresponding author

\section{A B S T R A C T}

Pumpkin belongs to cucurbitaceae family grown widely in tropical and sub-tropical

Keywords

Dehydration, Pre-

Treatments,

Pumpkin Flour,

Quality, Storage

Article Info

Accepted:

22 January 2019

Available Online:

10 February 2019 countries. Pumpkins are the sources of various functional compounds such as carotenoids, vitamins, minerals, dietary fibres, etc. Therefore, an attempt was made by drying of pumpkin for production of flour and its quality evaluation during storage. Different pre-treatments were applied to pumpkin shreds to standardize the method for preparation of pumpkin flour on the basis of chemical quality. The flour prepared from the best recipe (steam blanching for 5 minutes + dipping in $750 \mathrm{ppm}$ KMS solution for 10 minutes followed by dehydration in mechanical cabinet drier ( $60 \pm 2$ for $16-18$ hours) was packed in low density polyethylene (LDPE) pouches and aluminium laminated pouches (ALP) and evaluated for quality attributes at intervals of 0,3 and 6 months at ambient temperature. The pumpkin flour can be stored for 6 months at ambient temperature in LDPE as well as ALP with minimal changes in quality attributes. However, ALP was found to be comparatively better packaging material than LDPE pouches.

\section{Introduction}

Pumpkin is one of the important vegetables of genus Cucurbita and family Cucurbitaceae. The genus Cucurbita is comprised of five domesticated species viz. Cucurbita moschata, Cucurbita pepo, Cucurbita maxima, Cucurbita ficifolia and Telfairia occidentalis (Caili et al., 2006). C. moschata, C. maxima and C. pepo are the commonly grown and economically important species (Sharma and Rao, 2013).
The common varieties of pumpkin are CM-14, Pusha Vishwas, Arka Chandan, Arka Suryamukhi, CM-350, NDPK-24 (Kalloo et al., 2006). There is a large variation in size, shape and color of pumpkin fruits. The average weight of fruit fluctuates between 8 and $10 \mathrm{~kg}$ and sometimes even up to $20 \mathrm{~kg}$ have been noticed (Seshadri, 1986). Pumpkin contains 88 per cent moisture, 4.08 per cent protein, 0.46 per cent fat, $15.27 \mathrm{mg} / 100 \mathrm{~g} \beta$ carotene, $14.49 \mathrm{mg} / 100 \mathrm{~g}$ ascorbic acid, 1.018 
per cent pectin, 0.62 per cent fiber, $8.3{ }^{0} \mathrm{~B}$ TSS and 0.064 per cent acidity (Dhiman et al., 2018). The minerals present in pumpkin flesh are calcium, potassium, sodium, copper, iron, magnesium and manganese. Besides high nutritional value, pumpkin possesses many medicinal properties and is a rich source of biologically active compounds such as carotenoids, zeaxanthin, vitamin E, ascorbic acid, phytosterols, selenium and linoleic acid, which acts as antioxidant in human nutrition. Carotenoids play an important role in human health by acting as biological antioxidants, protecting cells and tissues from the damaging effects of free radicals and singlet oxygen (Jurgita et al., 2014).

Though pumpkin has been appreciated for high yields, good storage, longer period of consumption, high nutritive value yet, like most vegetables, it is a perishable crop whose characteristics change with time. Moreover, due to its bulkiness and large size, there are chances that it may get spoiled easily when it is cut open. Further, the large size and heaviness reduce its consumer acceptance and possess transportation problems (Pawar et al., 1985).

There are various methods which are used to preserve fruits and vegetables but most commonly used method is drying and dehydration. It is considered to be the oldest and the most important method of food preservation (Sacilik, 2007). Fruits and vegetables when converted into powders/flours have many benefits and economic potentials such as reduced volume, weight, packaging, easier handling, transportation, consumption and longer shelf life over their liquid counterpart (Phisut, 2012). Hence, keeping in view the abundant availability and functional significance of pumpkin the present study was undertaken to develop pumpkin flour and its quality evaluation during storage.

\section{Materials and Methods}

The fully ripe pumpkins were procured from local market/Sabzi mandi of Solan and the packaging materials like Low Density Polyethylene (LDPE) pouches and Aluminum Laminated Pouches (ALP) were also brought from the Solan market.

\section{Development and Standardization of technique for preparation of pumpkin flour}

The ripe pumpkins were washed and cut into halves. After removing the fluffy portion/brains/fibrous strands and seeds, the halves were cut into slices. The slices were peeled, washed, cut into pieces and grated to convert into shreds with the help of a greater. The shreds thus prepared were subjected to different pre-treatments for preparation of flour.

\section{Control (T1)}

The pumpkin shreds used without any pretreatment.

\section{Blanching (T2)}

The prepared shreds were subjected to water and steam blanching treatments separately for different time period i.e. 1, 2, 3, 4, 5, 6 and 7 minutes in order to select the best treatment on the basis of peroxidase test and nutritional retention.

\section{Blanching + Citric acid (T3)}

The blanched shreds were treated with different combinations of citric acid concentration $(0.25,0.5,0.75$ and $1.0 \%)$ and dipping time $(5,10,15$ and 20 minutes). The shreds after treating were subjected to sensory evaluation by a panel of ten judges for selection of the best treatment. 


\section{Blanching + KMS (T4)}

The blanched shreds were treated using different concentration of KMS (250, 500, 750 and $1000 \mathrm{ppm})$ and time of dipping $(5,10,15$ and 20 minutes). The shreds were then subjected to sensory evaluation by a panel of ten judges for selection of the best treatment. The shreds of different selected pre-treatments were dried in different lots in a mechanical dehydrator at $60 \pm 2{ }^{\circ} \mathrm{C}$ for $16-18$ hours prior to grinding into flours. The dried shreds were ground using a mechanical grinder. The grinded material was sieved through a 30 mesh metallic sieve to yield flour. The flour prepared was packed in two different packaging materials viz. Low density polyethylene (LDPE) pouches and Aluminum Laminated pouches (ALP). The packed flour was stored under ambient temperature for quality evaluation (chemical, functional and physical characteristics) at 0,3 and 6 months intervals.

\section{Physico-chemical, functional analysis and sensory evaluation}

The color of pumpkin flesh and peel was observed by Royal Horticulture Society color charts. Rehydration ratio, protein, fat, $\beta$ carotene, ascorbic acid and fiber content of pumpkin flour were estimated according to standard procedures by Ranganna (2009). Moisture and ash content of pumpkin flour was determined by method of AOAC (2012). Carbohydrate content and energy value was calculated by differential method of AOAC (1980). The water activity of pumpkin flour was estimated by computer digital water activity meter $\left(\mathrm{HW}_{3}\right.$ model, Rotronic International, Switzerland). Bulk density of pumpkin flour was measured by the method suggested by Rana et al., (2015). Water and oil absorption capacity of pumpkin flour was determined as per the procedure of Sosulski $e t$ al., (1976). Foaming capacity and foaming stability was calculated by the method described by Narayana and Narsinga Rao (1982). Nine point hedonic scale method proposed by Amerine et al., (1965) was followed for conducting the sensory evaluation of products. A panel of ten judges comprising of faculty members and post graduate students of the department of Food Science and Technology, Dr YS Parmar University of Horticulture and Forestry, Nauni, Solan (HP) were selected with care to evaluate the products for various sensory parameters such as color, texture, flavor, aroma and overall acceptability

\section{Statistical analysis}

Data on physico-chemical characteristics of pumpkin and pumpkin flour before and during storage was analyzed by Completely Randomized Design (CRD) suggested by Cochran and Cox (1967). While Randomized Complete Block Design (RBD) as described by Mahony (1985) was used to analyze the data pertaining to sensory evaluation. The experiment for recipe standardization and storage studies was replicated three times.

\section{Results and Discussion}

\section{Chemical characteristics of ripe pumpkin}

The data pertaining to chemical characteristics of ripe pumpkin are represented in Table 1 .

\section{Standardization of method for preparation of pumpkin flour}

The results of blanching type and time treatment of pumpkin shreds are based upon the negative (-ve) peroxidase test. The pumpkin shreds showed negative peroxidase test after 4 minutes in water blanching and 5 minutes in steam blanching. Though the time duration in steam blanching was more than water blanching but keeping in view the retention of ascorbic acid and $\beta$-carotene which was more in steam blanching i.e. 83.26 and 80.54 per cent, respectively than water 
blanching i.e. 75.13 and 71.1 per cent, respectively (Table 2). Therefore, steam blanching for 5 minutes was selected. The pumpkin shreds (steam blanching for 5 minutes) were subjected to different concentrations of citric acid solutions with varied time of dipping.

The data in (Table 3) shows that the highest mean scores for color (8.52), texture (8.50), flavor (8.45) and overall acceptability (8.55) are received by $\mathrm{CA}_{6}$ (steam blanching for 5 minutes +0.5 per cent citric acid dip for 10 minutes). Similarly, steam blanched pumpkin shreds were treated with different KMS solutions with varied time of dipping. The sensory evaluation data (Table 4) indicates that the maximum scores for color (8.67), texture (8.47), aroma (8.65), and overall acceptability (8.53) are obtained by $\mathrm{KMS}_{7}$ (steam blanching for 5 minutes $+750 \mathrm{ppm}$ KMS dip for 10 minutes).

\section{Chemical and functional characteristics of pumpkin flour}

The data on chemical and functional characteristics of pumpkin flour with different treatments $\left(T_{1}, T_{2}, T_{3}\right.$ and $\left.T_{4}\right)$ are shown in Table 5.

\section{Storage studies of pumpkin flour}

There was a non-significant effect of packaging material on rehydration ratio, foaming stability, fiber and ash content of pumpkin flour during storage period of 6 months. The overall effect of storage period reveals decrease in rehydration ratio from initial mean value of 6.03 to 5.91 during 6 months which was might be attributed to the reduction in water binding sites due to chemical and structural changes in major components of the product (Fig. 1a). Our findings are in conformity with the results of Karki (2009) in carrot pomace powder and Sharma et al., (2011) in peach, plum and apricot fruit powders. Due to the overall effect of storage period of 6 months, foaming stability of pumpkin flour decreased from initial mean value of 6.76 to 6.14 per cent which was might be due to loss in functional quality of protein (Fig. 2e).

Table.1 Chemical characteristics of ripe pumpkin

\begin{tabular}{|l|c|}
\hline \multicolumn{1}{|c|}{ Characteristics } & Pumpkin (Mean \pm S.E) \\
\hline Moisture $(\%)$ & $86.10 \pm 2.38$ \\
\hline Total soluble solids $\left({ }^{\circ} \mathrm{B}\right)$ & $8.00 \pm 0.72$ \\
\hline Titrable acidity $(\%)$ & $0.06 \pm 0.01$ \\
\hline$\beta$-carotene $(\mathrm{mg} / 100 \mathrm{~g})$ & $15.83 \pm 1.01$ \\
\hline Ascorbic acid $(\mathrm{mg} / 100 \mathrm{~g})$ & $14.18 \pm 0.94$ \\
\hline Crude fibre $(\%)$ & $0.64 \pm 0.02$ \\
\hline Ash $(\%)$ & $0.88 \pm 0.04$ \\
\hline Crude Fat $(\%)$ & $0.56 \pm 0.10$ \\
\hline Crude Protein $(\%)$ & $1.45 \pm 0.13$ \\
\hline Carbohydrate $(\%)$ & $10.35 \pm 2.34$ \\
\hline Energy value $(\mathrm{Kcal})$ & $52.29 \pm 9.45$ \\
\hline
\end{tabular}


Table.2 Effect of blanching on ascorbic acid and $\beta$-carotene content of pumpkin shreds

\begin{tabular}{|c|c|c|c|c|c|c|}
\hline \multirow[t]{2}{*}{ Blanching } & \multirow{2}{*}{$\begin{array}{l}\text { Ascorbic } \\
\text { acid } \\
(\mathbf{m g} / 100 g)\end{array}$} & \multicolumn{2}{|c|}{ Ascorbic acid (\%) } & \multirow{2}{*}{$\begin{array}{l}\beta \text {-carotene } \\
(\mathrm{mg} / 100 \mathrm{~g})\end{array}$} & \multicolumn{2}{|c|}{$\beta$-carotene (\%) } \\
\hline & & Retention & Loss & & Retention & Loss \\
\hline Without blanching & 16.25 & - & - & 15.68 & - & - \\
\hline Water blanching & 12.21 & 75.13 & 24.87 & 11.15 & 71.1 & 28.9 \\
\hline Steam blanching & 13.53 & 83.26 & 16.74 & 12.63 & 80.54 & 19.46 \\
\hline
\end{tabular}

Table.3 Sensory evaluation score* of pumpkin shreds treated with different concentration of citric acid and time of dipping

\begin{tabular}{|lllll|}
\hline \multicolumn{1}{|c}{ Treatment } & Colour & Texture & Flavour & Overall acceptability \\
\hline $\mathrm{CA}_{1}(0.25 \%$ for 5 minutes $)$ & 8.22 & 8.28 & 7.71 & 7.65 \\
\hline $\mathrm{CA}_{2}(0.50 \%$ for 5 minutes $)$ & 8.28 & 8.35 & 7.82 & 7.82 \\
\hline $\mathrm{CA}_{3}(0.75 \%$ for 5 minutes $)$ & 8.34 & 8.44 & 7.90 & 7.96 \\
\hline $\mathrm{CA}_{4}(1.00 \%$ for 5 minutes $)$ & 8.40 & 8.41 & 8.15 & 8.14 \\
\hline $\mathrm{CA}_{5}(0.25 \%$ for 10 minutes $)$ & 8.42 & 8.46 & 8.32 & 8.36 \\
\hline $\mathrm{CA}_{6}(0.50 \%$ for 10 minutes $)$ & $\mathbf{8 . 5 2}$ & $\mathbf{8 . 5 0}$ & $\mathbf{8 . 4 5}$ & $\mathbf{8 . 5 5}$ \\
\hline $\mathrm{CA}_{7}(0.75 \%$ for 10 minutes $)$ & 8.45 & 8.43 & 8.36 & 8.52 \\
\hline $\mathrm{CA}_{8}(1.00 \%$ for 10 minutes $)$ & 8.43 & 8.38 & 8.27 & 8.47 \\
\hline $\mathrm{CA}_{9}(0.25 \%$ for 15 minutes $)$ & 8.36 & 8.40 & 8.14 & 8.42 \\
\hline $\mathrm{CA}_{10}(0.50 \%$ for 15 minutes $)$ & 8.25 & 8.34 & 8.04 & 8.06 \\
\hline $\mathrm{CA}_{11}(0.75 \%$ for 15 minutes $)$ & 8.11 & 8.30 & 7.86 & 7.81 \\
\hline $\mathrm{CA}_{12}(1.00 \%$ for 15 minutes $)$ & 7.89 & 8.25 & 7.53 & 7.63 \\
\hline $\mathrm{CA}_{13}(0.25 \%$ for 20 minutes $)$ & 7.82 & 8.32 & 7.36 & 7.48 \\
\hline $\mathrm{CA}_{14}(0.50 \%$ for 20 minutes $)$ & 7.73 & 8.18 & 7.18 & $\mathbf{0 . 0 4}$ \\
\hline $\mathrm{CA}_{15}(0.75 \%$ for 20 minutes $)$ & 7.62 & 8.11 & 6.94 & 6.87 \\
\hline $\mathrm{CA}_{16}(1.00 \%$ for 20 minutes $)$ & 7.51 & 8.05 & $\mathbf{0 . 0 4}$ & $\mathbf{0 . 0 6}$ \\
\hline $\mathrm{CD}_{0.05}$ & & & & \\
\hline
\end{tabular}


Table.4 Sensory evaluation score of pumpkin shreds treated with different concentration of KMS and time of dipping

\begin{tabular}{|c|c|c|c|c|}
\hline Treatment & Colour & Texture & Aroma & Overall acceptability \\
\hline $\mathrm{KMS}_{1}(250 \mathrm{ppm}$ for 5 minutes $)$ & 8.12 & 8.24 & 7.84 & 7.94 \\
\hline $\mathrm{KMS}_{2}(500 \mathrm{ppm}$ for 5 minutes $)$ & 8.20 & 8.27 & 8.06 & 8.07 \\
\hline $\mathrm{KMS}_{3}(750 \mathrm{ppm}$ for 5 minutes $)$ & 8.36 & 8.32 & 8.15 & 8.15 \\
\hline $\mathrm{KMS}_{4}(1000 \mathrm{ppm}$ for 5 minutes $)$ & 8.32 & 8.35 & 8.31 & 8.23 \\
\hline $\mathrm{KMS}_{5}(250 \mathrm{ppm}$ for 10 minutes $)$ & 8.44 & 8.40 & 8.42 & 8.34 \\
\hline $\mathrm{KMS}_{6}(500 \mathrm{ppm}$ for 10 minutes $)$ & 8.51 & 8.43 & 8.53 & 8.46 \\
\hline $\mathrm{KMS}_{7}(750 \mathrm{ppm}$ for 10 minutes $)$ & 8.67 & 8.47 & 8.65 & 8.53 \\
\hline $\mathrm{KMS}_{8}(1000 \mathrm{ppm}$ for 10 minutes $)$ & 8.62 & 8.42 & 8.37 & 8.45 \\
\hline $\mathrm{KMS}_{9}(250 \mathrm{ppm}$ for 15 minutes $)$ & 8.60 & 8.37 & 8.16 & 8.36 \\
\hline $\mathrm{KMS}_{10}(500 \mathrm{ppm}$ for 15 minutes $)$ & 8.56 & 8.33 & 7.95 & 8.25 \\
\hline $\mathrm{KMS}_{11}(750 \mathrm{ppm}$ for 15 minutes $)$ & 8.48 & 8.28 & 7.77 & 8.18 \\
\hline $\mathrm{KMS}_{12}$ (1000 ppm for 15 minutes) & 8.40 & 8.24 & 7.53 & 8.07 \\
\hline $\mathrm{KMS}_{13}(250 \mathrm{ppm}$ for 20 minutes $)$ & 8.36 & 8.19 & 7.25 & 7.94 \\
\hline $\mathrm{KMS}_{14}(500 \mathrm{ppm}$ for 20 minutes $)$ & 8.30 & 8.14 & 7.06 & 7.82 \\
\hline $\mathrm{KMS}_{15}$ (750 ppm for 20 minutes) & 8.25 & 8.10 & 6.72 & 7.63 \\
\hline $\mathrm{KMS}_{16}$ (1000 ppm for 20 minutes) & 8.22 & 8.06 & 6.27 & 7.43 \\
\hline $\mathrm{CD}_{0.05}$ & 0.03 & 0.04 & 0.02 & 0.02 \\
\hline
\end{tabular}

Table.5 Chemical and functional characteristics of pumpkin flour

\begin{tabular}{|c|c|c|c|c|}
\hline Chemical characteristes & $\left(\mathbf{T}_{1}\right)$ & $\left(T_{2}\right)$ & $\left(\mathbf{T}_{3}\right)$ & $\left(\mathbf{T}_{4}\right)$ \\
\hline Moisture (\%) & $6.94 \pm 0.10$ & $5.55 \pm 0.31$ & $6.27 \pm 0.32$ & $6.58 \pm 0.25$ \\
\hline Water activity $\left(a_{w}\right)$ & $0.28 \pm 0.03$ & $0.21 \pm 0.01$ & $0.21 \pm 0.01$ & $0.24 \pm 0.01$ \\
\hline Ash (\%) & $5.54 \pm 0.40$ & $5.52 \pm 0.08$ & $5.51 \pm 0.29$ & $5.53 \pm 0.07$ \\
\hline Fat (\%) & $1.83 \pm 0.30$ & $1.56 \pm 0.17$ & $1.21 \pm 0.12$ & $1.40 \pm 0.18$ \\
\hline Fibre (\%) & $2.72 \pm 0.04$ & $2.67 \pm 0.05$ & $2.65 \pm 0.04$ & $2.70 \pm 0.04$ \\
\hline Protein $(\%)$ & $5.72 \pm 0.06$ & $5.83 \pm 0.05$ & $5.64 \pm 0.06$ & $5.87 \pm 0.04$ \\
\hline Ascorbic acid (mg/100 g) & $24.43 \pm 0.66$ & $19.37 \pm 1.66$ & $20.55 \pm 1.03$ & $21.60 \pm 1.11$ \\
\hline$\beta$-carotene $(\mathrm{mg} / 100 \mathrm{~g})$ & $15.43 \pm 0.95$ & $18.36 \pm 0.83$ & $15.47 \pm 0.71$ & $19.55 \pm 0.82$ \\
\hline Carbohydrate $(\%)$ & $77.25 \pm 0.51$ & $77.28 \pm 0.37$ & $78.72 \pm 0.18$ & $77.92 \pm 0.34$ \\
\hline Energy value (Kcal) & $348.38 \pm 1.01$ & $346.51 \pm 1.75$ & $348.33 \pm 1.30$ & $347.76 \pm 1.29$ \\
\hline \multicolumn{5}{|l|}{ Functional characteristics } \\
\hline Bulk density $(\mathrm{g} / \mathrm{ml})$ & $0.60 \pm 0.01$ & $0.65 \pm 0.01$ & $0.59 \pm 0.01$ & $0.61 \pm 0.01$ \\
\hline $\begin{array}{l}\text { Water absorption capacity } \\
(\mathrm{g} / \mathrm{g})\end{array}$ & $2.56 \pm 0.18$ & $4.24 \pm 0.12$ & $7.55 \pm 0.31$ & $3.59 \pm 0.08$ \\
\hline $\begin{array}{l}\text { Oil absorption capacity } \\
(\mathrm{g} / \mathrm{g})\end{array}$ & $1.36 \pm 0.10$ & $1.67 \pm 0.07$ & $1.62 \pm 0.08$ & $1.69 \pm 0.03$ \\
\hline Foaming capacity (\%) & $6.54 \pm 0.42$ & $7.62 \pm 0.40$ & $5.46 \pm 0.42$ & $7.91 \pm 0.34$ \\
\hline Foaming stability (\%) & $6.06 \pm 1.04$ & $6.65 \pm 1.06$ & $5.56 \pm 1.13$ & $8.75 \pm 0.97$ \\
\hline
\end{tabular}


Fig.1 Storage studies of pumpkin flour

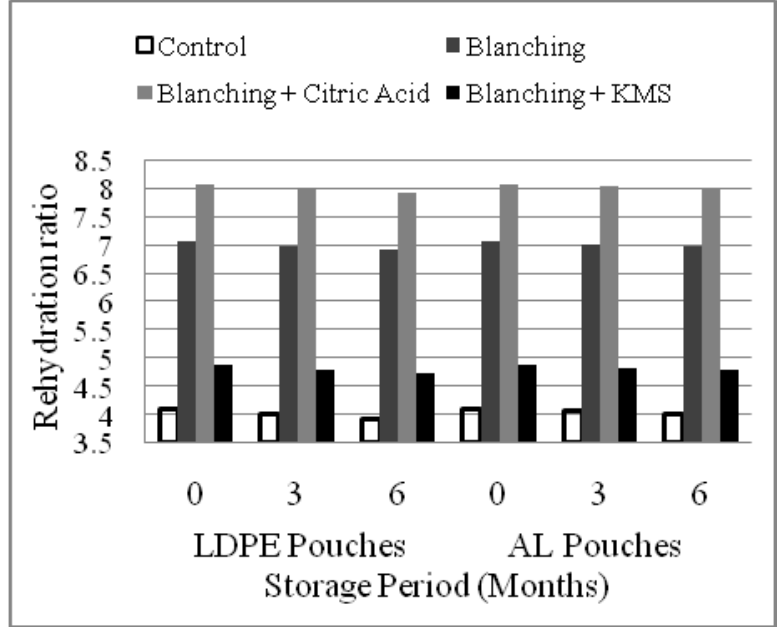

(a)

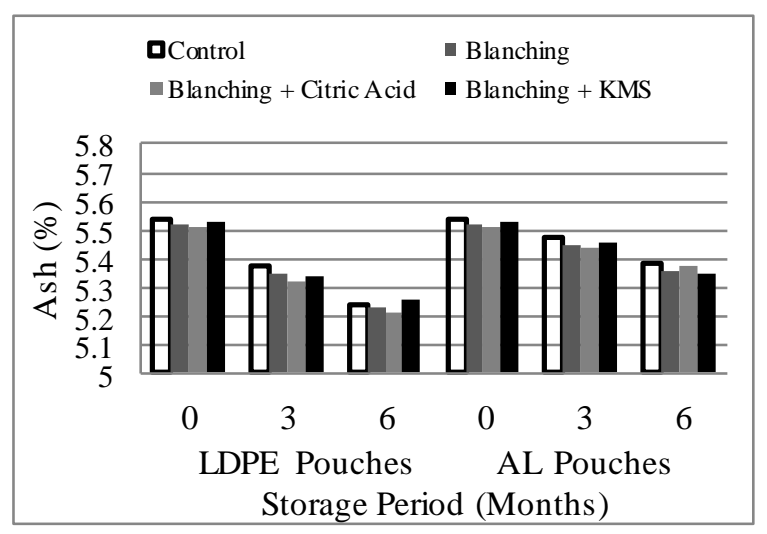

(c)

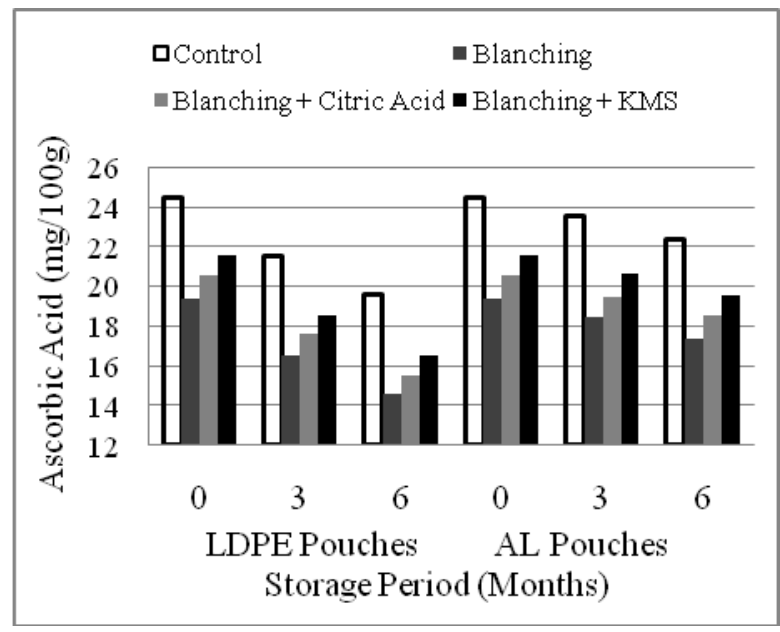

(e)

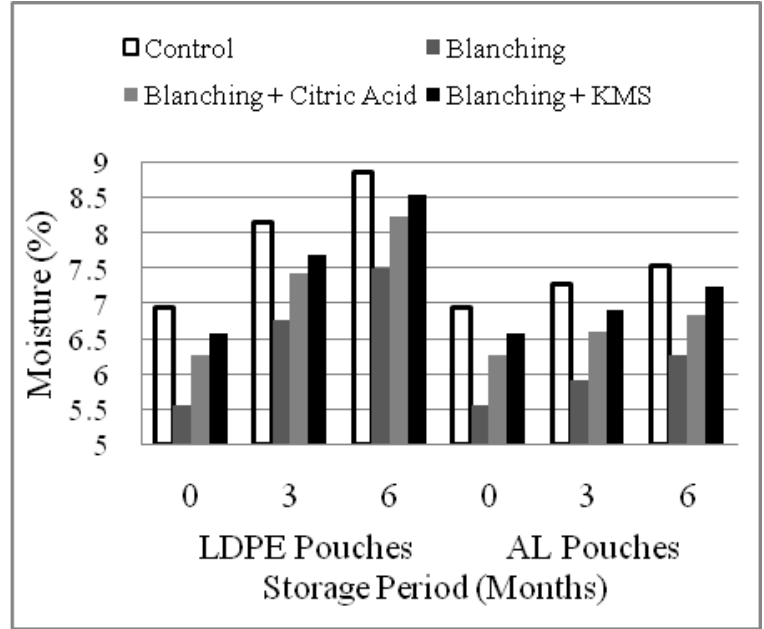

(b)

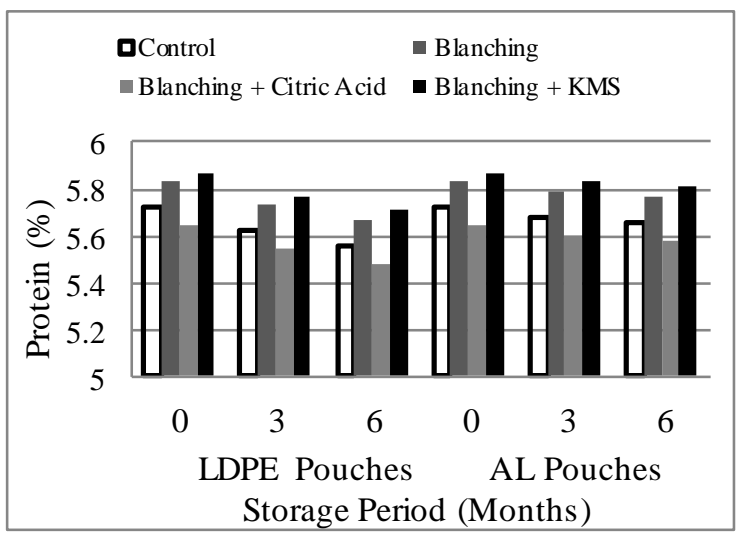

(d)

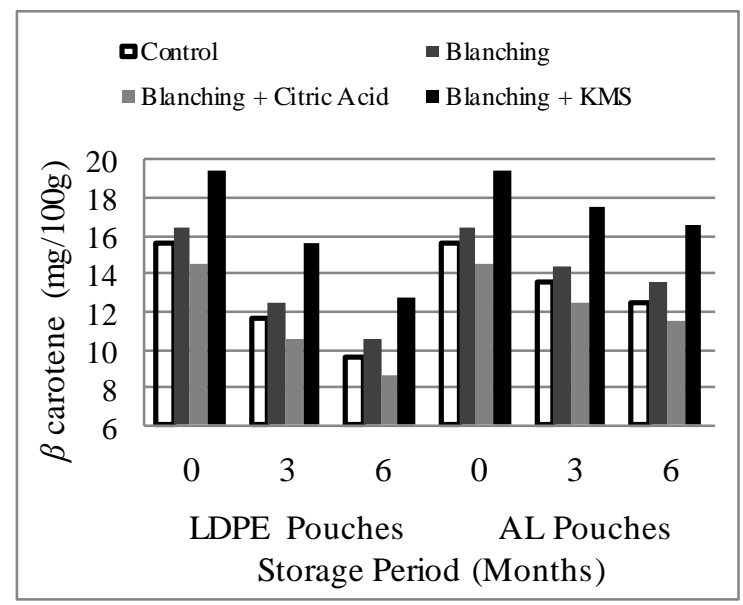

(f) 
Fig.2 Storage studies of pumpkin flour

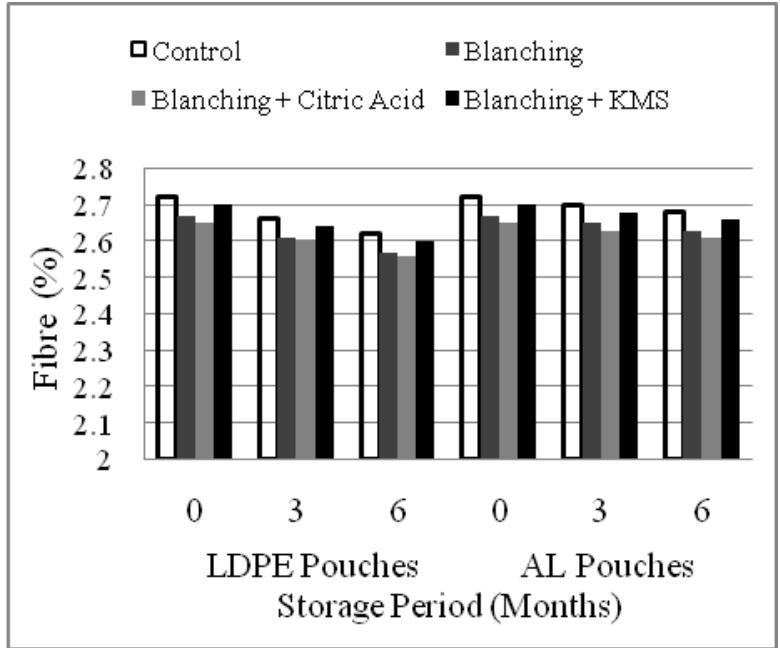

(a)

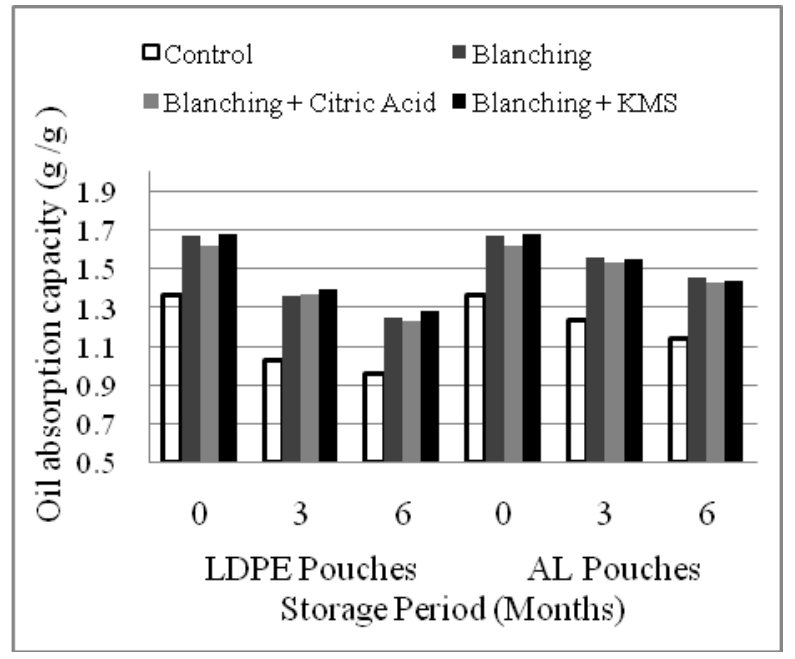

(c)

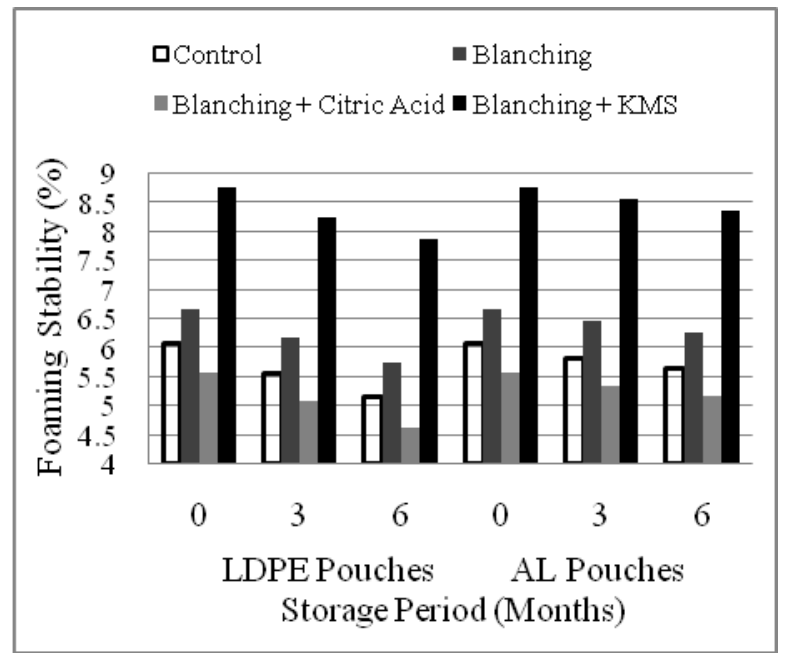

(e)

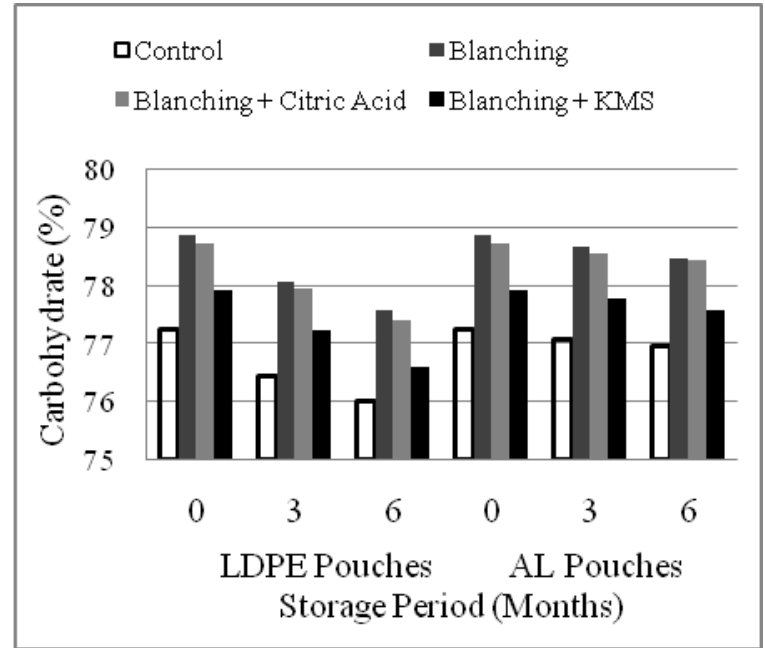

(b)

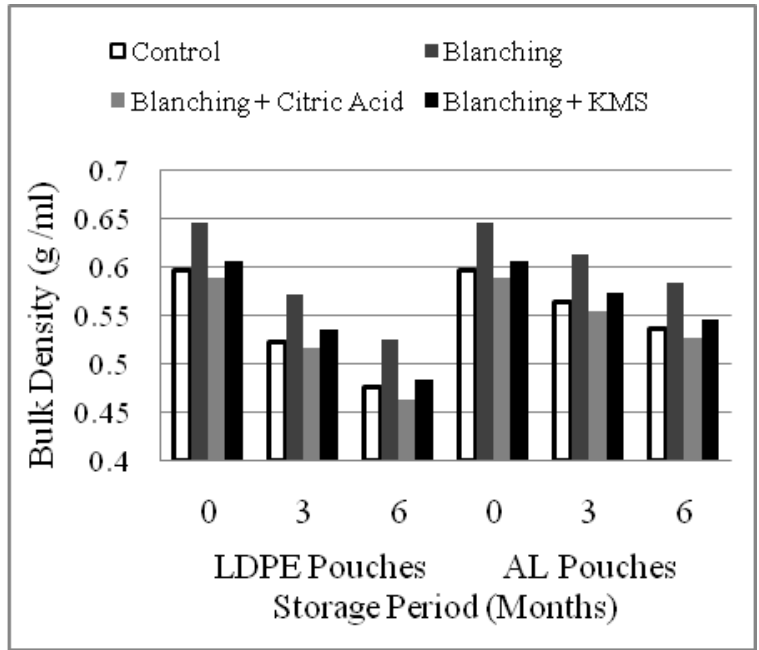

(d)

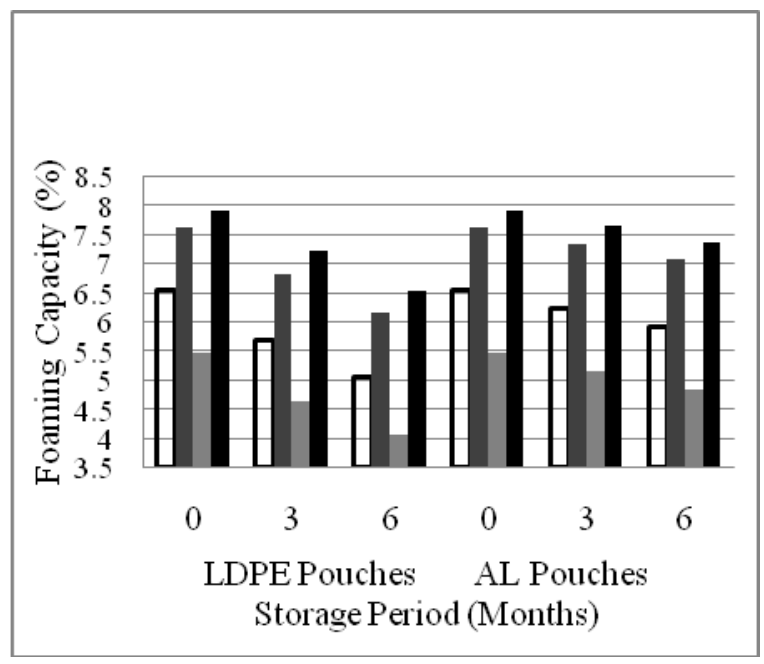

(f) 
The overall effect of storage period reveals a decrease in fiber content of pumpkin flour from an initial mean value of 2.69 to 2.62 per cent during 6 months of storage which was might be due to solubilization of polysaccharides (Fig. 2a). The present results are in agreement with those of Misra and Kulshrestha (2003) and Obadina et al., (2016) in potato flour and cocoyam flour, respectively. The overall effect of storage period of 6 months depicts decrease from initial mean value of 5.56 to 5.31 per cent in ash content which was might be either attributed to absorption of moisture by flour or due to biochemical activities by microorganisms (Fig. 1c). A similar decreasing trend for ash content during storage has been reported by Sharma et al. (2002) in lemon powder, Misra and Kulshrestha (2003) in potato flour and Kumar and Thakur (2017) in Indian horse chest nut flour.

The pumpkin flour showed a significant increase in moisture content from mean value of 6.33 to 8.28 and 6.98 per cent in LDPE pouches and ALP, respectively during storage of 6 months (Fig. 1b). The increase in moisture might be due to the hygroscopic nature of flour. The more uptake of moisture in flour packed in LDPE pouches might be due to high permeability to air and moisture. Almost the same trend of change in moisture content has been observed in apple powder by Sharma et al. (2003), in ginger powder by Rahman et al., (2013) and in spray dried papaya powder Wong and Lim (2016).

A significant decrease in bulk density, oil absorption capacity, foaming capacity, protein, ascorbic acid, $\beta$-carotene, carbohydrate content was recorded in pumpkin flour during the storage period of 6 months. The bulk density was found to decrease from initial mean value of 0.609 to $0.487 \mathrm{~g} / \mathrm{ml}$ in LDPE pouches and $0.548 \mathrm{~g} / \mathrm{ml}$ in ALP (Fig. 2d). This may be attributed to the increase in moisture content which affects the flour particle size. Similar trend of results has been revealed by Obadina et al., (2016) in cocoyam flour, Kumar and Thakur (2017) in Indian horse chestnut flour, Adebowale et al., (2017) in water yam flour. A decrease in oil absorption capacity from initial mean value of 1.58 to 1.18 and $1.37 \mathrm{~g} / \mathrm{g}$ was observed in pumpkin flour packed in LDPE pouches and ALP, respectively (Fig. 2c).

The decrease was might be due to reduced ability of the flours to entrap fat to its apolar end of protein chain as a result of decrease in protein content (Adeleke and Odedeji, 2010). Similar trend of results have been reported by Adebowale et al., (2017) in water yam flour and Akusu and Kinn (2013) in ogbono flour. Similarly, foaming capacity of pumpkin flour was also found to decrease from mean value of 6.88 to 5.45 per cent in LDPE pouches and 6.30 per cent in ALP during storage of 6 months (Fig. 2f). These results are in compliance with the findings of Giami et al., (2000) in African breadfruit seed flour.

The protein content of pumpkin flour was found to decrease from initial mean value of 5.77 to 5.61 and 5.71 per cent in LDPE pouches and ALP, respectively during 6 months of storage which was might be due to their denaturation and breakdown into smaller peptides (Fig. 1d). Our results are in conformity with the findings of Misra and Kulshrestha (2003) in potato flour, Butt et al., (2004) in wheat flour and Shahzadi et al., (2005) in composite flour. A decrease in ascorbic acid content from mean value of 21.49 to $16.56 \mathrm{mg} / 100 \mathrm{~g}$ in LDPE pouches and $19.47 \mathrm{mg} / 100 \mathrm{~g}$ in ALP was recorded in pumpkin flour stored for 6 months (Fig. 1e). The decline was more in LDPE pouches due to reaction by light because of transparency in nature. The loss during storage might be attributed to its oxidation to dehydroascorbic acid followed by the hydrolysis of 
dehydroascorbic acid to 2, 3-diketogluconic acids, which then undergoes polymerization to other nutritionally inactive products. The findings of the present study are in agreement with the results noticed by Sharma et al., (2003), Rahman et al., (2013) and Verma et al., (2015) in apple powder, ginger powder and guava powder, respectively.

The $\beta$-carotene content of pumpkin flour was found to decrease from an initial mean value of 16.45 to 10.35 and $13.56 \mathrm{mg} / 100 \mathrm{~g}$ in LDPE pouches and ALP, respectively during storage of 6 months (Fig. 1f). The retention was more in ALP was due to barrier properties to the light. The loss was might be due to the photosensitive nature, isomerization and epoxide forming nature of carotene and oxidative degradation of carotenoids during storage. These results are similar to the findings of Kulkarni and Joshi (2014) in pumpkin flour and Wong and Lim (2016) in spray dried papaya powder. The pumpkin flour showed a slight decrease in carbohydrate content from mean value of 78.19 to 76.90 per cent in LDPE pouches and 77.86 per cent in ALP during 6 months storage (Fig. 2b). The decrease was might be attributed to increase in moisture content which leads to rapid growth of microorganisms whose metabolic activities causes production of enzymes amylases that catalyze biochemical reactions which breakdown carbohydrates in food (Achi and Akubor, 2000). The results are in accordance with the findings of Obadina et al., (2016) in cocoyam flour and Adebowale et al., (2017) in water yam flour.

In conclusion, pumpkin can be dried and converted into flour of high nutritive value with health benefits. The pre-treatment standardized for preparation of pumpkin flour was steam blanching for $5 \mathrm{~min}+750 \mathrm{ppm}$ KMS dip for 10 minutes on the basis of chemical quality. The pumpkin flour can be stored for 6 months at ambient temperature in
LDPE pouches and ALP with minimal changes in quality attributes. However, comparatively fewer changes were observed in flour packed in ALP than LDPE pouches.

\section{References}

Achi, O.K., and Akubor, P.I. 2000. Microbiological characterization of yam fermentation for Elubo (yam flour) production. World Journal of Microbiology and Biotechnology. 16: 3-7.

Adebowale, A.A., Owo, H.O., Sobukola, O.P., Obadina, O.A., Kajihausa, O.E., Adegunwa, M.O., Sanni, L.O., and Tomlins, K. 2017. Influence of storage conditions and packaging materials on some quality attributes of water yam flour. Cogent Food and Agriculture. 3: 1-26.

Adeleke, R.O., and Odedeji, J.O. 2010. Functional properties of wheat and sweet potato flour blends. Pakistan Journal of Nutrition. 9: 535-538.

Akusu, O.M., and Kinn, D.B. 2013. Effect of storage period on selected functional, chemical stability and sensory properties of bush mango (Irvingia gabonensis) seed flour. African Journal of Food Science and Technology. 4: 136-140.

Amerine, M.A., Pangborn, R.M., and Roessler, E.B. 1965. Principles of Sensory Evaluation of Food. In: Food Science and Technology: A Serious of Monographs. Academic Press, New York, London. pp.277-372.

AOAC. 1980. Official methods of analysis, 13th ed. Association of Official Analytical Chemists, Washington, DC.

AOAC. 2012. Official Methods of Analysis. 19th ed. Association of Offical Analytical Chemists. Washington DC.

Butt, M.S., Nasir, M., Akhtar, S., and Sharif, K. 2004. Effect of moisture and packaging on the shelf life of wheat flour. Internet Journal of Food Safety. 4: 1-6.

Caili, F.U., Huan, S.H.I., and Quanhong, L.I. 
2006. A review on pharmacological activities and utilization technologies of pumpkin. Plant Foods for Human Nutrition. 61: 73-80.

Cochran, W.G., and Cox, C.M. 1967. Experimental Design. John Wiley and Sons, New York. pp. 171-217.

Dhiman, Anju. K., Bavita, K., Attri, S., and Ramachandran, P. 2018. Preparation of pumpkin powder and pumpkin seed kernel powder for supplementation in weaning mix and cookies. International Journal of Chemical Studies. 6: 167-175.

Giami, S.Y., Adindu, M.N., Akusu, M.O., and Emelike, J.N. 2000. Compositional, functional and storage properties of flours from raw and heat processed African breadfruit (Treculia Africana Decne) seeds. Plant Foods for Human Nutrition. 55: 357368.

Jurgita, K., Elvyra, J., Honorata, D., Judita, C., Agata, W., Jadwiga, H., and Edita, J. 2014. Chemical composition of pumpkin flesh flours used for food. Journal of Food, Agriculture and Environment. 12: 61-64.

Kalloo, G., Rai, M., Kumar, R., Prasana, H.I., Singh, M., Kumar, S., Singh, B., Ram, D., Pandey, S., Lal, H., Rai, S., Pandey, K.K., and Sathpathy, S. 2006. New vegetable varieties from IIVR Varanasi. Indian Horticulture. 51: 16-22.

Karki, S. 2009. Development and evaluation of functional food products from carrot pomace. M.Sc. Thesis. Department of Food Science and Technology, Dr YS Parmar University of Horticulture and Forestry, Solan. 121p

Kulkarni, A.S., and Joshi, D.C. 2014. Influence of storage temperature on chemical and microbial quality of carotene rich pumpkin powder. International Journal of Agriculture, Environment and Biotechnology. 7: 421-426.

Kumar, P., and Thakur, N.S. 2017. Studies on changes in quality characteristics of Indian horse chestnut (Aesculus indica Colebr.) flour during storage. Journal of Applied and Natural Science. 9: 445-450.

Mahony, M.O. 1985. Sensory evaluation of food. In: Statistical Methods and Procedures. Marcel Dekker Inc., New York.

Misra, A., and Kulshrestha, K. 2003. Effect of storage on nutritional value of potato flour made from three potato varieties. Plant Foods for Human Nutrition. 58: 1-10.

Narayana, K., and Narsinga Rao, M.S. 1982. Functional properties of war and heat processed winged bean (Psophocarpus tetragonolobus) flour. Journal of Food Science. 42: 534-538.

Obadina, A., Ashimolowo, H., and Olotu, I. 2016. Quality changes in cocoyam flours during storage. Food Science and Nutrition. 4: 818-827.

Pawar, V.D., Patil, D.A., Khedkar, D.M., and Ingle, V. 1985. Studies on drying and dehydration of pumpkin. Indian Food Packer. 39: 58-68.

Phisut, N. 2012. Spray drying technique of fruit juice powder: Some factors influencing the properties of product. International Food Research Journal. 19: 1297-1306.

Rahman, M.J., Talukder, M.A.I., Rani, L., Saha, K.C., and Nahid, M.S.I. 2013. The effect of processing techniques on the shelf life, nutritional and sensory quality of ginger (Zingiber officinale) powder and paste. Journal of Innovation and Development Strategy. 7: 60-66.

Rana, S., Gupta, S., Rana, A., and Bhushan, S. 2015. Functional Properties, phenolic constituents and antioxidant potential of industrial apple pomace for utilization as active food ingredient. Food Science and Human Wellness. 4: 180-187.

Ranganna, S. 2009. Handbook of Analysis and Quality Control for Fruit and Vegetable Products. Tata McGraw Hill, New Delhi. 1112p.

Sacilik, K. 2007. Effect of drying methods on 
thin-layer drying characteristics of hull-less seed pumpkin (Cucurbita Pepo L.). Journal of Food Engineering. 79: 23-30.

Seshadri, V.S. 1986. Cucurbits. In: Vegetable Crops in India (Bose, T.K., and Som, M.G. eds). NayaPrakash, Calcutta. 1015p.

Shahzadi, N., Butt, M.S., Rehman, S.U., and Sharif, K. 2005. Chemical characteristics of various composite flours. International Journal of Agriculture and Biology. 7: 105108.

Sharma, K.D., Alkesh., and Kaushal, B.B.L. 2003. Quality of apple powder as affected by packaging material during storage. Journal of Scientific and Industrial Research. 62: 609-615.

Sharma, K.D., Sharma, R., and Attri, S. 2011. Instant value added products from dehydrated peach, plum and apricot fruits. Indian Journal of Natural Products and Resources. 2: 409-420.

Sharma, S., and Rao, R.T.V. 2013. Nutritional quality characteristics of pumpkin fruit as revealed by its bio-chemical analysis.
International Food Research Journal. 20: 2309-2316.

Sharma, S.K., Sharma, P.C., and Kaushal, B.B.L. 2002. Storage studies of foam mat dried hill lemon (Citrus pseudolimon Tan.) juice powder. Journal of Food Science and Technology. 38: 553-556.

Sosulski, F.W., Garatt, M.O., and Slinkard, A.E. 1976. Functional properties of ten legume flours. International Journal of Food Science of Technology. 9: 66-69.

Verma, M., Singh, J., Kaur, D., Mishra, V., and Rai, G.K. 2015. Effect of various dehydration methods and storage on physicochemical properties of guava powder. Journal of Food Science and Technology. 52: 528-534.

Wong, C.W., and Lim, W.T. 2016. Storage stability of spray-dried papaya (Carica papaya $\mathrm{L}$.) powder packaged in aluminium laminated polyethylene (ALP) and polyethylene terephthalate (PET). International Food Research Journal. 23: 1887-1894.

\section{How to cite this article:}

Sachin Mitta, Anju K Dhiman, Anshu Sharma, Surekha Attri and Deepika Kathuria. 2019. Standardization of Recipes for Preparation of Pumpkin (Cucurbita moschata) Flour and its Quality Evaluation during Storage. Int.J.Curr.Microbiol.App.Sci. 8(02): 3224-3235. doi: https://doi.org/10.20546/ijcmas.2019.802.377 